\title{
The emergence of the grammatical paradigm of nominal determiners in French and in Romance: Comparative and diachronic perspectives
}

\author{
ANNE CARLIER \\ Université Charles-de Gaule Lille3 \\ anne.carlier@univ-lille3.fr \\ and \\ BÉATRICE LAMIROY \\ University of Leuven \\ beatrice.lamiroy@kuleuven.be
}

\begin{abstract}
This article is devoted to the emergence of a new paradigm in French and Romance: that of nominal determiners. Latin had no articles, and although possessives, demonstratives and indefinites could determine the noun, they could also be used as pronouns or adjectives, so that the morpho-syntactic category of nominal determiners did not exist as such. We first examine the diachronic evolution of French, where a far-reaching grammaticalization process took place. Syntagmatically, all determiners end up in the NP-initial position as the only available syntactic slot, contributing to the highly configurational NP pattern characteristic of Modern French. From a paradigmatic viewpoint, determiners no longer correspond to a syntactic function, but to a separate morpho-syntactic category. We also evaluate to what extent this evolution took place in two other Romance languages, Italian and Spanish. Through the analysis of this particular evolution, based on parallel corpora consisting of a Latin text and its translations in Old, Middle, and Modern French on the one hand, and in Spanish and Italian on the other, our study also provides evidence for more general mechanisms, analogy in particular, at work in the creation of new paradigms.
\end{abstract}

Keywords: Analogy, French, Romance, Grammaticalization, Nominal Determiner

Part of this research has been carried out in the framework of the ANR-DFG project PaLaFra (ANR-14-FRAL-0006). We are grateful to two anonymous reviewers for their detailed and useful comments on the submitted version. All remaining errors are of course ours. 


\section{Résumé}

Cet article est consacré à l'émergence d'un nouveau paradigme grammatical en français et dans les langues romanes, celui de la détermination nominale. Le latin n'avait pas d'articles, alors que les possessifs, les démonstratifs et les indéfinis, tout en pouvant servir de déterminant nominal, étaient par ailleurs utilisés comme pronom ou adjectif. La détermination nominale en tant que catégorie morpho-syntaxique autonome était donc inexistante. Nous examinons d'abord comment a eu lieu, au cours de l'évolution diachronique du français, un processus important de grammaticalisation. Syntagmatiquement, tous les déterminants se retrouvent dans la position initiale du NP comme seule position syntaxique disponible, ce qui contribue au caractère hautement configurationnel du constituant nominal du français moderne. D'un point de vue paradigmatique, les déterminants ne correspondent plus à une fonction syntaxique, mais à une catégorie morphosyntaxique distincte. Nous évaluons ensuite dans quelle mesure cette évolution a eu lieu dans deux autres langues romanes, l'italien et l'espagnol. Notre analyse est basée sur des corpus parallèles comprenant un texte latin et ses traductions en français médiéval et moderne, d'une part, et ses traductions en espagnol et en italien, d'autre part. Elle met en évidence des mécanismes et des motivations plus généraux, notamment l'analogie, qui sont à l'œuvre dans la création de nouveaux paradigmes.

Mots-clés: Analogie, français, langues romanes, grammaticalisation, détermination nominale

\section{INTRODUCTION}

This article is devoted to the emergence of a new paradigm in French and Romance: that of nominal determiners. ${ }^{1}$ In this section, we set forth our claims, the theoretical framework that accounts for the data, viz. grammaticalization in relation to construction grammar, and the method on which the analysis is based, namely a study of parallel corpora.

\subsection{The emergence of new grammatical paradigms}

As is well known, Latin has no articles. Moreover, although Latin has demonstratives, possessives and indefinites, these can be used both as pronouns and as adjectives (Menge 2000, inter alia). Hence, the concept of nominal determiner in Latin does not correspond to a separate morphosyntactic category (or form class), but rather to a syntactic function. From Latin to French, the following evolutions can be observed: on the one hand, French develops a complete paradigm of both definite and indefinite articles; on the other hand, as will be shown here, demonstratives, possessives and indefinites have grammaticalized following the same path as the articles, ending up in the initial position of the nominal constituent as the only available syntactic slot. In other words, in Modern French, determiners no longer correspond to a

\footnotetext{
${ }^{1}$ ACC: accusative; COND: conditional; DEF.ART: definite article; DEM: demonstrative; F: feminine; FR : French ; IMPF: imperfect; INDEF.ART: indefinite article; INF: infinitive; IT : Italian ; M: masculine; N: noun; NEG: negative; NOM: nominative; NP: Noun Phrase; Part.art: partitive article; PL: plural; POSS: possessive; PP: Prepositional Phrase; PRS: present; PST: past; REL: relative; sG: singular; sUBJ: subjunctive ; SP : Spanish.
} 
syntactic function, but to a morphosyntactic category of their own. As a consequence of this evolution, the paradigm of nominal determiners contains, from a synchronic viewpoint, a sub-paradigm of highly grammaticalized members - the articles besides more weakly grammaticalized determiners such as demonstratives, possessives and indefinites. ${ }^{2}$

Through the analysis of this particular evolution from Latin to French, ${ }^{3}$ our study may shed light on more general mechanisms at work in the creation of new grammatical paradigms, analogy in particular. The diachronic perspective is combined here with a comparative analysis of three modern Romance languages: French, Italian and Spanish, which shows that the grammaticalization process is most advanced in French and least in Spanish, Italian being in between.

\subsection{Theoretical framework}

Meillet (1912), in his seminal article about grammaticalization, wrote:

De ce qu'un mot est groupé avec un autre d'une manière qui tend à devenir fixe dans certains cas, il résulte pour ce mot la perte d'une partie de son sens concret dans ces constructions.

(Meillet 1912:136). ${ }^{4}$

'From the fact that a word is grouped with another in a way that tends to become fixed in certain cases, it results that this word loses part of its concrete meaning in these constructions.'

In line with this insight, the focus of grammaticalization studies has shifted in recent years from the study of individual morphemes towards the constructions in which these morphemes are embedded (Gisborne and Patten 2011, Traugott and Trousdale 2013). One of our assumptions here is that the NP structure played a crucial role in the evolution of nominal determination in Romance, and particularly so in French. Another important development in grammaticalization theory is the acknowledgement of the role of analogy in grammaticalization: whereas for Meillet, grammaticalization and analogy are two distinct mechanisms in language change, Fischer (2008) argues that analogy is not only one of the mechanisms at work in grammaticalization, but also its driving force.

Interestingly, our analysis suggests that the analogical processes involved in language change are similar to those involved in language acquisition as described by Tomasello (2003): as we will show, both pattern-finding, that is, the ability to create syntactic types out of frequent tokens, and system mapping, that is, the ability to apply the same pattern to another set, played a crucial role in the

\footnotetext{
${ }^{2}$ Adpositions offer another example of a grammatical paradigm containing several subparadigms. For instance, French, à 'to' and $d e$ 'of' are highly grammaticalized prepositions, and sur 'on', dans 'in' exhibit an intermediate degree of grammaticalization, while à cause $d e$ 'because of' or en face de 'in front of' are weakly grammaticalized.

${ }^{3}$ This analysis is based on earlier research on articles and determiners (Carlier 2007, 2011, 2013; Carlier and De Mulder 2010; Carlier and Lamiroy 2014; De Mulder and Carlier 2006, 2012.

${ }^{4}$ Emphasis is ours.
} 
development of Romance articles and determiners. Analogy acts both on the syntagmatic and on the paradigmatic axis (Anttila 2003, Fischer 2008:15): from a syntagmatic point of view, frequent patterns at token level tend to become routinized (Bybee 2003) and, hence, expand to an increasingly higher type level within the same structure; at the same time, in this pattern, frequent forms at token level tend to attract other forms with a similar function in their slot, which in turn may give rise to entirely new paradigms, or to new morphosyntactic categories.

In section 2, we provide evidence for the above hypotheses by focusing, in the evolution from Latin to Modern French, on the emergence of articles and nominal determiners, both paradigms leading to a highly configurational NP pattern in Modern French. In section 3, we will evaluate the extent to which the same evolution took place in two other Romance languages, viz. Italian and Spanish.

\subsection{Methodology}

Our analysis is based on parallel corpora that allow this double perspective - both diachronic and comparative.

On the one hand, we reconstruct the evolution from Latin to French by comparing a Classical Latin text, namely Cicero's De Inventione, with its Old French and Modern French translations. On the other hand, we compare three modern translations, in French, Italian and Spanish, of the same Latin source text (see the list of corpora).

This research is intended as a pilot study, as it is restricted to 200 examples, manually aligned, for each language or language stage. Depending on the availability of large aligned parallel corpora in the future, a large-scale investigation on the same topic could be undertaken.

\section{From LATIN TO FrenCH}

In the present section, we examine the diachronic evolution of French with regard to nominal determination and analyze which mechanisms led to the emergence and development of an autonomous paradigm of nominal determiners in Modern French.

\subsection{Statistical data}

The relative frequency of nominal determiners in our sample is shown in Table 1 and in Figure 1 below. In Classical Latin, zero marking is overwhelmingly dominant (77\%). In Old French, zero marking remains important (32\%), but has become less frequent than the definite article (40\%). In contrast, the indefinite article derived from the unity numeral is still in a primitive stage: its frequency is low (8\%), its conditions of use are restricted (Carlier 2013), and it is still in competition with other indefinite determiners such as aucun 'some', certain 'certain'. In Modern French, the indefinite singular article is more frequent (21\%) and a new indefinite article is available for mass and plural count nouns, the so-called partitive (Carlier 2007). As a result of the development and further expansion of the articles, zero 


\begin{tabular}{lrcc}
\hline \hline & Latin & Old French & Modern French \\
\hline Possessives & $4 \%$ & $6 \%$ & $10 \%$ \\
Demonstratives & $5 \%$ & $4 \%$ & $6 \%$ \\
Relative pronouns & $3 \%$ & $4 \%$ & $0 \%$ \\
Identity markers & $3 \%$ & $2 \%$ & $3 \%$ \\
Definite article & $0 \%$ & $40 \%$ & $44 \%$ \\
Interrogative or indefinite determiners & $7 \%$ & $5 \%$ & $3 \%$ \\
Unity numeral or indefinite article & $2 \%$ & $8 \%$ & $21 \%$ \\
Partitive article & $0 \%$ & $0 \%$ & $8 \%$ \\
Zero marking & $77 \%$ & $32 \%$ & $6 \%$ \\
\hline \hline
\end{tabular}

Table 1: Relative frequency of nominal determination in the Latin corpus and its Old French and Modern French translation

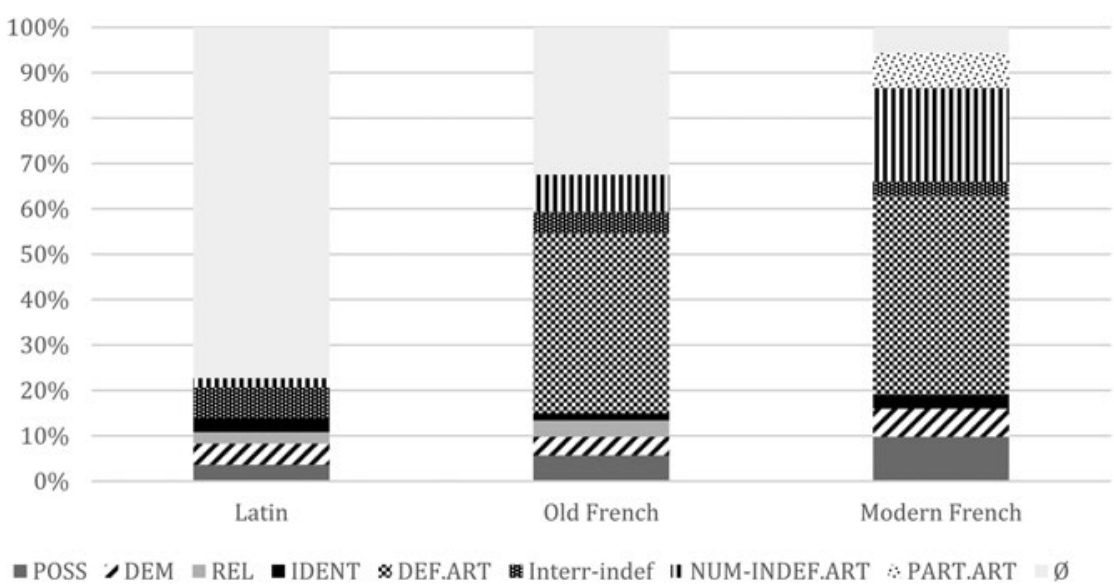

Figure 1: Relative frequency of nominal determination in the Latin corpus and its Old French and Modern French translation

determination has become exceptional (6\%). Interestingly, in present-day French, stronger markers of definiteness, such as possessives, demonstratives and identity markers, expand and compete with the definite article, suggesting an ongoing semantic weakening of the definite article and, hence, a further step in the grammaticalization process (Harris 1978, Marchello-Nizia 1992, De Mulder and Carlier 2006).

\subsection{Diachronic analysis of nominal determiners in French}

The emergence of a new grammatical paradigm of nominal determiners can be described as consisting of several stages, which can be empirically observed in historical corpora. 


\subsubsection{Overview}

Stage I: Classical Latin

Paradigmatic axis: No marker. Zero marking is the default case

Syntagmatic axis: No fixed pattern

Stage II: Late Latin

Paradigmatic axis: Competition among different markers. Proliferation of multiple variants, for enhanced expressivity. All markers have globally the same pragmatic or discursive function, but, at least partially, conserve their primitive meaning and are semantically distinct.

Syntagmatic axis: Statistical tendencies towards a dominant pattern

Stage III: Late Latin > Old French

Paradigmatic axis: Selection among different markers. Less paradigmatic variation, leading to a high token frequency of a few markers, or even a single marker, viz. the definite article. The selected marker undergoes desemantization as well as formal erosion.

Syntagmatic axis: Emergence of the pattern DEFINITE ARTICLE + NOUN

Stage IV: Middle French

Paradigmatic axis: Token frequency > Type frequency. Due to analogy, the high token frequency of this marker serves as an attraction pole for other markers, leading to a new morphosyntactic paradigm of both definite and indefinite articles.

Syntagmatic axis: Emergence of the pattern ARTICLE + NOUN

Stage V: from Middle French to Modern French

Paradigmatic axis: Type frequency $>$ Abstract type frequency. Repetition of the same process by analogy on a more abstract level, leading to a morphosyntactic paradigm of nominal determiners.

Syntagmatic axis: Emergence of the pattern DETERMINER + NOUN

As mentioned above, the mechanisms at work in the development of the paradigm of articles and determiners are similar to the analogical processes that have been identified as characteristic of language acquisition by Tomasello (2003). In stage III, on the basis of the high token frequency of the definite article combined to a noun, a pattern will be recognized. In this pattern, the position occupied by the definite article becomes, by a process of schematization, a slot for expressions with a similar function, which includes the indefinite (derived from the numeral) and the partitive (originally $d e$ 'of, from' + definite article), thus leading to a new type, that of the article (stage IV). Finally, the same pattern will be mapped onto an even more abstract level, so that the article slot will eventually host various other expressions such as indefinites, possessives, and demonstratives, yielding a new paradigm, viz. the paradigm of nominal determiners (stage V).

\subsubsection{Stage I: No marking}

As we have already mentioned, Latin has no articles and no paradigm of nominal determiners (Carlier 2011). The distinction between determiners and pronouns for 
demonstratives, possessives and indefinites is not to be conceived in terms of an opposition between two morpho-syntactic categories, but corresponds only to a functional difference. Moreover, there is a fuzzy boundary between determiners and adjectives. Thus, multus 'many' can appear in the structural position of a determiner, before N' (1a), or be coordinated with an adjective (1b).
a. Multi
docti
homines
many-NOM.M.PL learned-NOM.M.PL man-NOM.M.PL 'many learned men'
(Cicero, Epistulae ad Familiares. 9,6,5)
b. Multi
ac summi
many-NOM.M.PL and important-NOM.M.PL 'many important men'
viri
man-NOM.M.PL
(Cicero, The Catiline Orations. 1: 10)

Similarly, there is a fuzzy boundary between pronouns and adverbs: multum for example is considered to be a neuter singular pronoun when it occupies a nominative or accusative argument position, yet it is analyzed as an adverb if there is no argument position available, as in example (2):
(2) Multum te amamus
a lot NOM/ACC.N.SG you-ACC love-PRs.1PL
'We love you very much'

(Cicero, Epistulae ad Atticum, 1,1,5)

Even when possessives, demonstratives and indefinites clearly function as nominal determiners, they are not constrained to a unique syntagmatic position: although dominantly in NP-initial position, they can also appear in final position (3), there can be several of them within one NP (4), and they can occur at both sides of the noun (5).

$\begin{array}{lll}\text { (3) } \begin{array}{l}\text { Sunt } \\ \text { be-PRS.1PL }\end{array} \text { however } & \text { bestiae } & \text { quaedam }, . . . \\ \text { 'there are however certain animals, ... } & \text { certain-NOM.F.PL }\end{array}$

(Cicero, De Finibus Bonorum et Malorum, V 38)

(4) idem ille populus

same-NOM.M.SG that-NOM.M.SG people-NOM.M.SG 'the same people over there'

(Cicero, Pro Sestio 105)

(5) hunc ornatum ... meum

this-ACC.SG decoration-ACC.SG my-ACC.SG

'this my decoration of mine / my decoration'

(Plautus, Amphitryon 46)

\subsubsection{Stage II: Competition between different markers of definiteness}

In Classical Latin, although pronouns are regularly used in order to determine the NP, bare NPs are far more common (cf. Fig. 1: 77 \% in our sample). In Late Latin, however, the number of markers indicating definiteness and anaphoricity dramatically increases, a characteristic of the second stage in the emergence of the paradigm of nominal determiners (see section 2.2.1). 
In the following example, different anaphoric markers (praedictus 'above-mentioned', ipse 'himself') are repeatedly used, although there is no risk of referential ambiguity: ${ }^{5}$

(6) Dum hec ageretur, Remistanius, filius Eudone quondam, fidem suam quod praedicto regi Pippino promiserat fefellit, et ad Waiofarium iterum ueniens, dictioni sue faciens. Quod Waiofarius cum magno gaudio eum recepit, et adiutorem sibi contra Francos uel praedicto rege eum instituit. Superscriptus Remistanius contra praedicto rege et Francos seu custodias quas ipse rex in ipsas ciuitates dimiserat, nimium infestus accessit, et Bitoriuo seu et Limoticino quod ipse rex adquisierat, praedando nimium uastauit, ita ut nullus colonus terre ad laborandum tam agris quam uineis colere non audebant. Praedictus rex Pippinus in Betoricas per hiemem totum cum regina sua Bertradane in palatium resedit.

(Fredegarius, Cont. $\S 50,8^{\text {th }}$ C.)

'Meanwhile Remistanius, son of the late Eudo, broke the oath of fealty that he had sworn to the aforementioned King Pippin. He went back to Waiofar and became his man. Waiofar was delighted to receive him and to make use of his help against the Franks and the aforementioned King. The aforementioned Remistianus attacked the aforementioned King and the Franks and the garrisons which this same king had left in the cities, and destroyed the districts of Berry and also the Limousin, that this same king had conquered and he did this so effectively that not a peasant dared work in the fields and vineyards. The aforementioned King Pippin spent the whole winter with Queen Bertrada in his residence at Bourges.'

From a paradigmatic viewpoint, different markers compete for the expression of definiteness. Although the identity marker ipse and the distal demonstrative ille become more frequent with respect to Classical Latin, the increase is not spectacular (see Table 2) and, in particular regarding ille, its extension in Merovingian Latin does not allow us to predict that it will grammaticalize from Old French onwards into several morpho-syntactic categories, viz. the definite article (li), the non-reflexive 3rd person pronoun $(i l)$, and the demonstrative ( cil<ecce-ille).

\begin{tabular}{|c|c|c|c|c|c|c|c|}
\hline & \multicolumn{4}{|c|}{ Demonstratives } & \multirow{2}{*}{\multicolumn{2}{|c|}{$\begin{array}{l}\text { Identity } \\
\text { Markers }\end{array}$}} & \multirow{3}{*}{$\begin{array}{l}\text { Total } \\
\text { occurrences }\end{array}$} \\
\hline & \multirow{2}{*}{$\begin{array}{l}1^{\text {st }} \mathrm{p} . \\
\text { hic }\end{array}$} & \multirow{2}{*}{$\begin{array}{l}2^{\text {nd }} \mathrm{p} . \\
\text { iste }\end{array}$} & \multirow{2}{*}{$\begin{array}{l}3^{\text {rd }} \mathrm{p} . \\
\text { ille }\end{array}$} & \multirow{2}{*}{$\begin{array}{l}\text { Neuter } \\
\text { is }\end{array}$} & & & \\
\hline & & & & & ipse & idem & \\
\hline Classical Latin & $29 \%$ & $3 \%$ & $9 \%$ & $46 \%$ & $8 \%$ & $5 \%$ & 3814 \\
\hline Late Latin $\left(7^{\text {th }}-10^{\text {th }} \mathrm{c}.\right)$ & $19 \%$ & $3 \%$ & $18 \%$ & $43 \%$ & $10 \%$ & $7 \%$ & 1727 \\
\hline
\end{tabular}

Table 2: Relative frequency of demonstratives and identity markers in Classical Latin and Late Latin ${ }^{6}$

\footnotetext{
${ }^{5}$ This proliferation of markers of definiteness and anaphoricity is not an idiosyncratic feature of the Fredegar chronicle, which was supposedly written by several authors. Similar observations have been made by Selig (1992) on the basis of another corpus.

${ }^{6}$ The figures for Classical Latin are based on the LASLA Corpus <web.philo.ulg.ac.be/ lasla> and for Late Latin on the Corptef Corpus of the Base du français médiéval, which was developed in the framework of the ANR Project Corpus représentatif des premiers
} 
From a syntagmatic viewpoint, the position of these elements with respect to the noun becomes less flexible and some pronoun-determiners tend to lose either their pronominal or their determiner use (Fruyt 2010).

\subsubsection{Stage III: Selection of a single definiteness marker}

During the transition from Late Latin to Early Old French, a single determiner - ille - is selected as the definite article, and therefore becomes very frequent: in our Old French corpus, the definite article is used in $40 \%$ of the NPs containing a common noun. Moreover, its syntagmatic position within the NP is fixed, according to the pattern DefinITE ARTICLE $+\mathrm{N}^{\prime}$, where $\mathrm{N}^{\prime}$ can contain modifiers such as pre-nominal or postnominal adjectives, adnominal PPs or relative clauses. As to the position of the modifiers with respect to the noun, adjectives remain flexible until the $15^{\text {th }} \mathrm{c}$. (7a). However, adnominal complements and relatives are exclusively post-nominal, with the exception of some fossilized collocations, like those in (7b) (Buridant 2000: 759).

(7) a. et li est le bec conjoint tout en tel maniere que se il fust conjoins a une espere, c'est a dire a reonde figure.

round shape

'and his beak is attached to his face as if it was attached to a sphere, that is to say a round shape'

(Magnus, De Falconibus, transl. ms. BFN nouv.acq. fr $188000,14^{\text {th }}$ c.)

la teste du faucon n' est pas de figure reonde

the-F.SG head of.the.M.SG falcon NEG be NEG of shape round

'the head of the falcon does not have a round shape'

(Magnus, De Falconibus, transl. ms. BFN nouv. acq fr 188000, 14th c.)

b. la roi cort; la $\frac{\text { Dieu merci }}{\text { kod }}$

the-r.sg king court, the-F.sG God grace

'the king's court'; 'God's grace'

(Chrestien de Troyes, Yvain, v. 946)

(Béroul, Tristan, v. 3427)

\subsubsection{Stage IV: Token frequency > Type frequency}

Given the high token frequency of the Old French definite article and the NP structure in which it is embedded, this combination will be identified as a pattern so that the slot hosting the definite article will progressively allow other expressions into the same pattern, such as the numeral uns 'one' or the partitive ( $d e$ 'of, from' + definite article). This process eventually gives rise to a new paradigm, that of the articles.

As can be seen on the graph below, uns has only an incipient article use in Old French, and is not fully grammaticalized until the $13^{\text {th }}-14^{\text {th }}$ century. ${ }^{7}$

textes français (Guillot and Carlier, 2018). They compare the relative frequency of the different demonstratives and identity markers with each other, but do not consider the relative frequency of these markers with respect to all NPs of the corpus.

${ }^{7}$ For more details on the progressive grammaticalization of uns in Old French, see Carlier (2013). 
Grammaticalization of the partitive construction into an indefinite article takes place in the $15^{\text {th }}$ century, that is, in Middle French, and correlates with a further tightening of the NP pattern (Carlier 2007). Whereas zero determination is still widespread and the position of the adjective with respect to the noun still fluctuates in Old French (7a), the pattern DET N X further generalizes from the $15^{\text {th }}$ century onwards and at the same time, postposition of the adjective becomes more and more systematic. However, the pre-nominal position remains available for a small set of semi-grammaticalized adjectives such as grand/petit 'big/small', bon/mauvais 'good/bad', vrai 'true', simple 'single', etc. ${ }^{8}$ In its emergent stage, the partitive article tends to occur in the pattern $\mathrm{N}+\mathrm{X}$ ( $\mathrm{X}$ being an adjective, a PP or a relative clause), but is infrequent in the older pattern ADJ + N (Carlier 2007, Carlier and Lamiroy 2014), as is shown by the contrast between (8a) and (8b), two translations of the same Latin source text. ${ }^{9}$

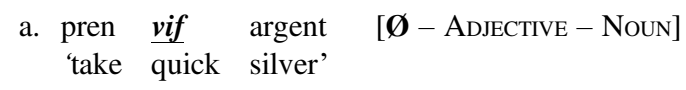

$$
\begin{aligned}
& \text { b. prenez de l' argent vif [Part.ARt. - Noun - Adjective] } \\
& \text { 'take of-the silver quick' }
\end{aligned}
$$

As a result of the expansion of the articles, zero determination in combination with a common noun has become exceptional in Modern French. Table 3 represents the progressive expansion of the articles according to different types of common nouns.

As Table 3 shows, the development of the partitive article leads to a profound restructuring of French grammatical morphology: whereas grammatical categories were encoded as post-nominal suffixes attached to each of the elements of the NP in Latin, they are exclusively expressed by NP-initial prenominal clitics in Modern French (the plural marker on the noun $-s$ being silent).
a. Ov-em/Ov-es emit. sheep-ACC.SG/ACC.PL buy-PRS.3sG
b. Il achète un/du/des mouton(s) PRO.3SG buy-PRS.3SG ART.INDEF-SG.COUNT/SG.MASS/PL.COUNT sheep.PL 'He buys a sheep / mutton / sheep'

Note however that the grammaticalization of the third article of the paradigm, the partitive $d e+$ DEFINITE ARTICLE, at the expense of zero marking, is not fully completed in Modern French: although its use is nearly systematic with concrete nouns, be they mass nouns or count nouns, it is still exceptional in PPs in combination with an abstract noun, as we show in Table 4.

\footnotetext{
${ }^{8}$ These adjectives express either quantity (e.g. simple 'single') or intensity (e.g. un piètre amant 'a poor lover') and are semantically bleached to the point that they can lose their semantic specificity (e.g. un grand médecin is also un bon médecin).

${ }^{9}$ The Latin source text is a treatise on falconry, entitled De Falconibus and written by Albertus Magnus in the $12^{\text {th }}$ c. Example (8a) is taken from the manuscript of the National Library of France fr. 2003, $15^{\text {th }}$ c., whereas (8b) comes from the manuscript National Library of France fr. 25342, $15^{\text {th }}$ c.
} 


\begin{tabular}{|c|c|c|c|c|c|}
\hline & & Singular Count & Plural Count & Mass & Abstract \\
\hline \multirow{2}{*}{$\begin{array}{c}14^{\text {th }} \\
\text { century }\end{array}$} & Definite & \multicolumn{3}{|c|}{ Weakened demonstrative } & \\
\hline & Indefinite & \multicolumn{2}{|c|}{ Unity Numeral/Zero ${ }^{10}$} & & \\
\hline & & & & & \\
\hline \multirow{3}{*}{$\begin{array}{l}15^{\text {th }}-16^{\text {th }} \\
\text { century }\end{array}$} & & Singular Count & Plural Count & Mass & Abstract \\
\hline & Definite & \multicolumn{3}{|c|}{ Weakened demonstrative } & \\
\hline & Indefinite & Unity Numeral & \multicolumn{2}{|c|}{ Partitive/ Zero } & \\
\hline & & & & & \\
\hline \multirow{3}{*}{$\begin{array}{l}17^{\text {th }}-18^{\text {th }} \\
\text { century }\end{array}$} & & Singular Count & Plural Count & Mass & Abstract \\
\hline & \begin{tabular}{|l|} 
Definite \\
\end{tabular} & \multicolumn{4}{|c|}{ Weakened demonstrative } \\
\hline & Indefinite & Unity Numeral & \multicolumn{3}{|c|}{ Partitive } \\
\hline
\end{tabular}

Table 3: Types of common nouns and progressive expansion of the articles

\begin{tabular}{lrcc}
\hline \hline & Partitive & $\varnothing$ - marking & Number of tokens \\
\hline sel, sucre, chocolat, lait & $89,6 \%$ & $10,1 \%$ & 352 \\
amour & $1,4 \%$ & $99,6 \%$ & 138 \\
\hline \hline
\end{tabular}

Table 4: Proportion between zero-marking and partitive in an NP included in a PP for mass nouns and abstract nouns in Modern French (Frantext, 1900-2016, www. frantext.fr, consulted 18-2-2016)
(10) a. Il prépare
he prepare-PRS.3sG
$\begin{array}{ll}\text { ce repas avec } & \emptyset / \text { de l' } \\ \text { this meal with } & \text { of the }\end{array}$
b. Il prépare
ce dessert avec
du / ?Ø (chocolat/sel/sucre/lait)
he prepare-PRS.3sG this dessert with of.the (chocolate/salt/sugar/milk)

\subsubsection{Stage V: Type frequency $>$ Abstract type frequency}

As we saw in stage IV, the frequent pattern Definite ArTiCLE $+\mathrm{N}^{\prime}$ expands to a typelevel, yielding the pattern ARTiCLE + N. As a result of analogy, the same process is

\footnotetext{
${ }^{10}$ For indefinite NPs containing plural count nouns, zero determination is the default case. However, the plural form uns is occasionally used, mostly for internal plurals (e.g. unes botes 'a pair of boots') but sometimes also for ordinary plurals. This plural form of the indefinite article $u n$ disappears in the $15^{\text {th }}$ century.
} 
repeated in stage $\mathrm{V}$, at a still higher level of abstraction, so that the article slot will host new expressions that behave like the articles, both paradigmatically and syntagmatically, viz. determiners.

From a syntagmatic viewpoint, demonstratives, possessives and indefinites tend to occupy the initial position of the nominal constituent, like the articles. Several patterns in which they can co-occur (11), appear in final position (12) or be coordinated with an adjective (13), all available in previous stages (Combettes 2001), are no longer possible in Modern French. ${ }^{11}$

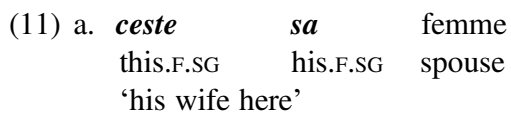

(Cent nouvelles nouvelles, $15^{\text {th }} \mathrm{c}$.)

b. cette votre chèvre

that.F.SG your.F.SG goat

'your goat over there'

(Victor Hugo, Notre-Dame de Paris, $19^{\text {th }}$ c.)

$\begin{array}{lllll}\text { (12) a. Ma dame a } & \text { roialme } & \text { pluseurs } \\ \text { my lady } & \text { have-PRS.3sG } & \text { kingdom } & \text { several-PL }\end{array}$

'my lady has several kingdoms' (Partonopeu, end $12^{\text {th }} \mathrm{c}$.)

b. il ne demeure femme nesune en tout mon regne PRO-3SG NEG remain-PRS.3SG wife no-F.SG in all my kingdom 'there remain no women throughout my reign' (Le roman de Bérinus, $14^{\text {th }} \mathrm{c}$.)

(13) l' humaine et nostre beaulté

the human-F.SG and our beauty

'our human beauty'

(Montaigne, Essais, $16^{\text {th }} \mathrm{c}$.)

From a paradigmatic viewpoint, a formal distinction is introduced rather systematically for the two functions, the nominal determiner and the pronominal one, as is illustrated in Table 5. For demonstratives, the distinction between pronouns and determiners is created by the adjunction of the non-clitic form of the $3^{\text {rd }}$ person pronoun. As to the indefinite determiner quelque 'some', the pronoun is similarly distinguished from the determiner by the adjunction of the pronoun -un. On the contrary, from chascun 'every/everyone', chaque is obtained by subtraction of -un. And finally, the distinction between the two functions for possessives is twofold: when used as a pronoun, on the one hand the form is stressed (whereas it is unstressed when it functions as a determiner) and, on the other, it contains the definite article as a nominalization marker.

\footnotetext{
${ }^{11}$ In Modern French, only quantifying expressions can be combined with other determiners, (e.g., tous les cinq jours, les quelques livres). As for autre et même, they can also appear together with a determiner, (e.g., les autres livres), arguably because they occupy an intermediate position on the cline Adjective > Determiner (Van Peteghem 2000).
} 


\begin{tabular}{lll}
\hline \hline Determiners & Pronouns & Meaning \\
\hline ce & ce-lui, ce-elle, ce-eux, ce-elles & Demonstrative \\
mon & le mien & Possessive \\
quelque(s) & 'suelqu'un, quelques-uns & 'each' \\
chascun $>$ chaque & cha(s)cun & (end \\
\hline \hline
\end{tabular}

Table 5: Formal distinction between determiners and pronouns in Modern French

\section{A COMPARISON BETWEEN FRENCH, ItALIAN AND SPANISH}

In this section we evaluate to what extent the evolution of French as sketched above also took place in two other Romance languages, Spanish and Italian.

\subsection{Statistical data}

As is shown in Table 6 and Figure 2, the relative frequency of the determiners in the Spanish corpus (Reyes Coria 1997) is to some extent comparable to the one we observed in the Old French data. Zero marking remains relatively robust $(20 \%)$. The definite article is dominant (45\%), whereas the indefinite article derived from the unity numeral remains underdeveloped (11\%) and, as will be illustrated below, still alternates with zero marking and indefinite determiners. Moreover, Spanish has no partitive article (Carlier and Lamiroy 2014). Finally, compared with French, where, between the medieval and the modern stage, strong definite markers, such as identity markers, demonstratives and possessives, increase in frequency compared to the definite article (Figure 1), the Spanish definite article does not seem to suffer from any competition with stronger definite markers.

The data of the Italian corpus (Greco 1998) show an intermediate position between French and Spanish. Zero marking is less frequent than in Spanish (15\%), while the indefinite singular article is in a more advanced stage of development than in Spanish. The intermediate position of Italian between French and Spanish is further confirmed by the fact that Italian has developed a partitive article, just as French has, although it varies substantially by region, being far more frequent in the North than in the South. It does not occur in Greco (1998). ${ }^{12}$

\subsection{Comparative analysis of nominal determination in Romance}

If one takes into account comparative data belonging to Romance languages other than French, in particular Spanish and Italian, the main observation is, as we will show below, that the three languages did not grammaticalize to the same extent in the domain of nominal determination. ${ }^{13}$

\footnotetext{
${ }^{12}$ This may be due to the geographic origin of the translator or to the conservative register of translations.

${ }^{13}$ As we have shown elsewhere, the same conclusion holds for many other components of language (Lamiroy 1999, Lamiroy 2003, Lamiroy and De Mulder 2011, Lahousse and Lamiroy 2012, De Mulder and Lamiroy 2012, Carlier et al. 2012, Carlier and Lamiroy 2014).
} 


\begin{tabular}{lrrr}
\hline \hline & Spanish & Italian & French \\
\hline Possessives & $5 \%$ & $7 \%$ & $10 \%$ \\
Demonstratives & $6 \%$ & $5 \%$ & $6 \%$ \\
Relative pronouns & $2 \%$ & $2 \%$ & $0 \%$ \\
Identity markers & $3 \%$ & $2 \%$ & $3 \%$ \\
Definite article & $45 \%$ & $43 \%$ & $44 \%$ \\
Interrogative or indefinite determiners & $8 \%$ & $7 \%$ & $3 \%$ \\
Unity numeral / indefinite article & $11 \%$ & $19 \%$ & $21 \%$ \\
Partitive article & $0 \%$ & $0 \%$ & $8 \%$ \\
Zero marking & $20 \%$ & $15 \%$ & $6 \%$ \\
\hline \hline
\end{tabular}

Table 6: Relative frequency of nominal determiners in the modern Spanish, Italian, and French translations of the Latin corpus

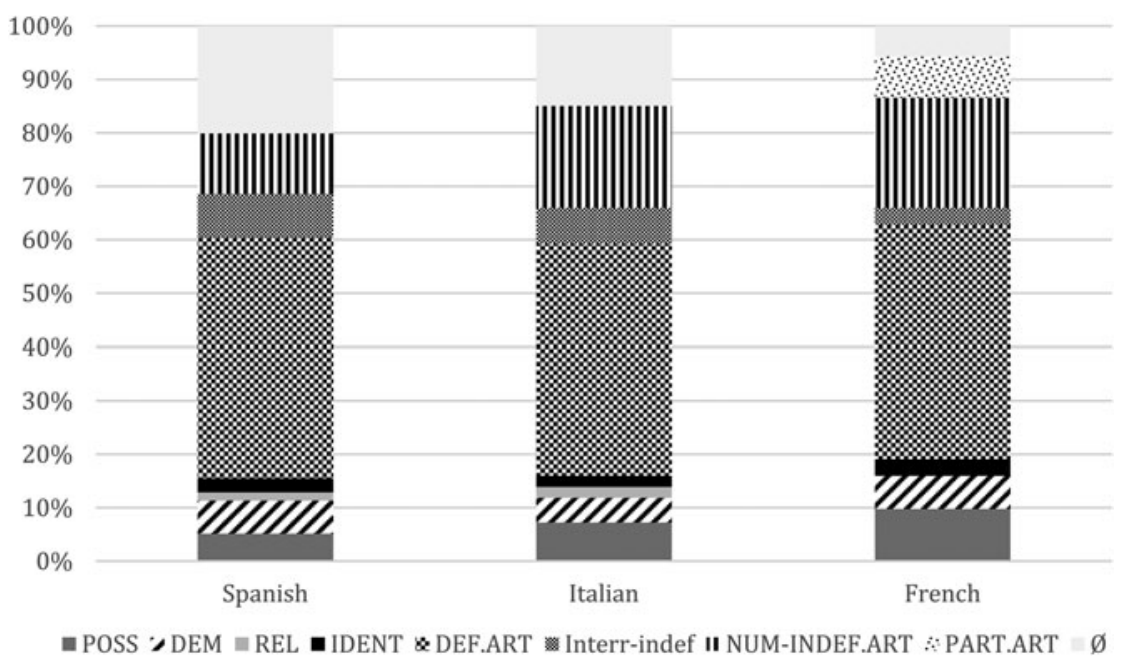

Figure 2: Relative frequency of nominal determination in the Spanish, Italian and French corpora

As mentioned above, Modern Spanish displays certain characteristics that we observed in Old French, at Stage III: whereas the definite article is well-established, the indefinite article is still in competition with various indefinite determiners (see (14)) and with the still-frequent zero marking (see (15)).

(14) a. SP En aquel tiempo, cierto varón, naturalmente grande y sabio, conoció qué materia había y cuánta oportunidad existía en los ánimos de los hombres para las cosas máximas.

b. IT In quel periodo, un uomo veramente grande e saggio riuscì a capire quale fosse la natura dell'animo umano e quanto grande fosse la sua capacità di fare cose straordinarie. 
c. FR À cette époque, un homme manifestement supérieur et sage comprit les capacités que contenait l'esprit humain et l'attitude remarquable de celui-ci à exécuter de très grandes choses.

'In those days, a man, naturally great and wise, understood the nature and the abilities of men to accomplish extraordinary things.'

(Cicero, De Inventione, I, 2)

(15) a. SP Si ha parido, con Ø varón se ha acostado.

b. IT Se ha partorito, è stata con un uomo.

c. FR Si elle a eu un enfant, c'est qu'elle a eu commerce avec un home.

'If she gave birth to a child, then she slept with a man.'

(Cicero, De Inventione, I, 73)

In Italian, both competition between the indefinite article and other indefinite markers on the one hand, and zero marking on the other, are not exceptional, as illustrated by (16b) and (17b), but as suggested by our corpus data, they are statistically less pervasive in Italian than in Spanish.

(16) a. SP Ciertos navegantes, siendo sacudidos por adversa tempestad en alta mar.

b. IT Alcuni marinai, sballottati in alto mare da una furiosa tempesta.

c. FR Des marins, alors qu'ils étaient au large, furent repoussés par des vents contraires.

'Some sailors were caught in a terrible storm while they were on high sea.'

(Cicero, De Inventione, II, 95)

(17) a. SP nadie habia visto $\emptyset$ nupcias legítimas

b. IT nessuno aveva conseguito $\emptyset$ nozze legittime

c. FR personne n'avait vu de mariage légitime

'Nobody had seen legal weddings.'

(Cicero, De Inventione, I, 2)

In what follows, we explore other facts of Spanish and Italian, in order to examine to what extent the category of articles and of nominal determiners are full-fledged paradigms, and how far the syntagmatic DET $+\mathrm{N}$ pattern is entrenched. We will show that all our data point toward a similar conclusion: the evolution is less advanced in Modern Spanish than in Modern French, while Italian occupies an intermediate position. We will do this by addressing the questions listed below, all of which receive a positive answer for Modern French:

(i) Is the determiner slot necessarily occupied? (i.e., has zero marking ceased to be possible?)

(ii) Is there, syntagmatically, a unique prenominal determiner slot?

(iii) Is there, paradigmatically, a separation between determiners and pronouns?

(iv) Is the noun slot necessarily occupied? (i.e. is noun ellipsis impossible?)

(v) Is the noun slot available only for nouns or are other morphosyntactic categories allowed?

With respect to question (i), as shown in Table 7 below, zero determination has become exceptional in Modern French; that is, it still occurs, but only in a few syntactic positions (PPs, vocatives, predicate nouns as well as in fossilized idioms). In 


\begin{tabular}{c|c|c|c|c|c}
\multicolumn{2}{c|}{} & Singular Count & Plural Count & Mass / Abstract \\
\hline \multirow{2}{*}{ SPANISH } & Definite & \multicolumn{3}{|c}{ Weakened demonstrative } \\
\cline { 2 - 5 } & Indefinite & Unity Numeral / Zero & & \\
\hline & & Singular Count & Plural Count & Mass / Abstract \\
\hline \multirow{3}{*}{ ITALIAN } & Definite & \multicolumn{4}{|c}{ Weakened demonstrative } \\
\cline { 2 - 6 } & Indefinite & Unity Numeral & Partitive/Zero (North) or Zero (South) \\
\hline \multicolumn{5}{|c|}{ Weakened demonstrative } \\
\hline \multirow{3}{*}{ FRENCH } & Definite & Singular Count & Plural Count & Mass / Abstract \\
\cline { 2 - 5 } & Indefinite & Unity Numeral & \multicolumn{3}{c}{ Partitive }
\end{tabular}

Table 7: Types of common nouns and distribution of the articles in Spanish, Italian and French

contrast, zero marking is still the only possible indefinite marker in Spanish for mass nouns and abstract (or generic) nouns, and it also remains common with count nouns. In Italian, zero marking is characterized by an important regional variation: it is still common in the South, but fading in the North (Carlier and Lamiroy 2014). Note that Spanish, which lacks a partitive article, still uses an indefinite marker, (alg)unos, with plural count nouns, as shown in (18).

(18) a. SP Vimos unos niños jugando en el parque.

b. IT Abbiamo visto (dei) bambini che giocavano nel parco.

c. FR Nous avons vu des enfants qui jouaient dans le parc.

'We saw children playing in the park.'

The distribution of prenominal determiners in these three languages correlates with the way plural marking on the noun is organized (Carlier and Lamiroy 2014), as we show in Table 8 .

\begin{tabular}{llll}
\hline \hline & Suffixal plural marking & Singular & Plural \\
\hline Spanish & $\varnothing$ vs $-s$ & casa mente libro & casa-s mente-s libro-s \\
Italian & No unique plural marking & casa cane libro braccio & cas-e can-i libr-ibracci-a \\
French & No audible plural marking & rose [Roz] livre [livR] & roses [Roz] livres [livR] \\
\hline \hline
\end{tabular}

Table 8: Suffixal plural marking in Spanish, Italian and French

\footnotetext{
${ }^{14}$ For indefinite NPs containing plural count nouns, there is a competition between $\varnothing$ and the plural form unos.
} 
In (spoken) French, where regular, audible plural marking on the noun has disappeared completely, final $-s$ being silent, pre-nominal determiners have become obligatory for all categories. Italian displays plural marking on the noun, but the morphemes used do not unambiguously mark plural. For example, final $e$ marks plural in cas-e 'houses', but it can also be the final vowel of a singular noun, as with cane 'dog' (Stark 2007). As these ambiguous plural endings are increasingly combined with pre-nominal markers, especially in the Northern variants, one could hypothesize that there is a correlation between ambiguous (and hence, less functional) plural endings and the increase of pre-nominal markers. In Spanish, where plural is consistently marked on all nouns by a final $-s$, pre-nominal zero marking is still quite common with all types of nouns. In other words, the three languages show that the presence of post-nominal inflectional marking neatly patterns with the absence of pre-nominal determiners, and vice-versa, as schematized in (19).

Noun-Gramm. Infl

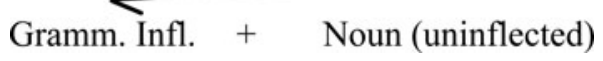

With respect to whether there is a unique determiner slot in NP-initial position (question (ii) above), the facts in Table 9 show that this is indeed the case in contemporary French. In both Spanish and Italian, in contrast, several determiners can appear within the NP in prenominal position, as illustrated in (20), (see (11) above for this pattern in older stages in French). Similarly, possessives can either be preposed or postposed (see (21)-(23) below), a pattern that exists only as an archaism in Modern French.

\begin{tabular}{llll}
\hline \hline Meaning & Spanish & Italian & French \\
\hline Demonstrative & PRO $=$ DET & PRO $=$ DET & PRO $\neq$ DET \\
Possessive & PRO $=$ DET $(1 \mathrm{PL}, 2 \mathrm{PL})$ & PRO $=$ DET & PRO $\neq$ DET \\
& PRO $\neq$ DET $(1 \mathrm{SG}, 2 \mathrm{SG}, 3 \mathrm{SG}, 3 \mathrm{PL})$ & & \\
'some' & PRO $=$ DET & PRO $=$ DET & PRO $\neq$ DET \\
\hline \hline
\end{tabular}

Table 9: Paradigms of Determiners vs Pronouns

(20)

a. IT Se un tuo vecino avesse un cavallo migliore

If a-M.SG your.M.SG neighbor have-SUBJ.3SG a horse better

che il tuo, preferiresti il tuo o

than the-M.SG your-M.SG prefer-COND.2SG the.M.SG your-M.SG or

il suo ?

the-M.SG his-M.SG

'If your neighbor had a better horse than yours, would you prefer yours or his ?'

(Cicero, De Inventione I, 52) 
b. SP Y llamó a aquel su compañero una y muchas and call-PST.3sg to that-M.SG his-M.SG companion one and many veces.

times

'And he called that companion of his several times.'

(Cicero, De Inventione I, 51)

What distinguishes Italian from Spanish, however, is that Italian, unlike Spanish, does not allow the postposition of demonstrative determiners, as illustrated in (21).

(21) Postnominal demonstratives: 'DET' + N + DEM

a. Spanish

$\begin{array}{lll}\text { la } & \text { casa } & \text { esa } \\ \text { the-F.SG } & \text { house } & \text { that-F.SG }\end{array}$

'that house'

b. Italian

* la casa questa

the-F.SG house that-F.SG

'that house'

c. French

Not attested

(22) Postnominal quantifiers: N + QUANTIFIER

a. Spanish

i. Hace todo sin esfuerzo alguno.

do-PRS.3SG all-SG without effort some-M.SG

'He does everything without any effort.'

ii. No hagan caso alguno de lo que dicen.

not make-SBJV.PrS.3PL case any-M.SG of it they say-PRS.3PL

'Don't pay any attention to what they say.'

b. Italian

senza sforzo alcuno

without effort some-M.SG

'without any effort'

c. French

sans effort aucun (archaic)

without effort some-M.SG

'without any effort'

(23) Postnominal possessors: 'DET' + N' + POsS

a. Spanish

i. el pequeño coche mio

the-M.SG small-M.SG car mine-M.SG

'my little car'

ii. algunos objetos suyos

some-M.PL object-PL his-M.PL

'some of his objects' 
b. Italian

$\begin{array}{lll}\text { i. la casa } & \text { vostra } \\ \text { the-F.SG house } & \text { your-F.SG } \\ \text { 'your house' } & \end{array}$

ii. quella amica sua

that-F.SG friend-F.SG his-F.SG

'that friend of his'
iii. un libro mio
a-M.SG book my-M.SG
'a book of mine'
iv. il libro mio e di Moravia
the-M.SG book my-M.SG and of Moravia
'my book and Moravia's'
v. un mio amico
a-M.SG my-M.sG friend
'a friend of mine'

c. French

une idée mienne (archaic)

a-F.SG idea my-F.SG

'an idea of mine'

With respect to question (iii), whether pronouns and determiners constitute separate paradigms, we saw in section 2 that the answer is positive for Modern French. In Italian and Spanish, however, demonstratives, possessives and certain indefinite markers use identical forms for pronouns and prenominal determiners, as illustrated below for the demonstrative in (24). The only exception here is the Spanish possessive which distinguishes between the two for $1^{\text {st }}, 2^{\text {nd }}, 3^{\text {rd }}$ person singular and $3^{\text {rd }}$ plural: $m i$, tu, su are determiners, whereas el mío, el tuyo, el suyo are pronouns. However, the overall situation suggests that whereas in French the two paradigms are fully established as separate morphosyntactic entities, the border between the two remains fuzzy in Spanish and Italian. As to French, the fact that the determiner is embedded in a very constrained construction pattern DET $+\mathrm{N}(+\mathrm{X})$ eventually led to its differentiation from the corresponding pronoun. ${ }^{15}$ Spanish and Italian maintained a more flexible NP pattern and consequently do not show the same tendency towards a specialization of the two morpho-syntactic categories.

\footnotetext{
${ }^{15}$ The studies included in Carlier and Combettes (2015) show that the tendency towards more specialized morpho-syntactic categories is a global evolutionary characteristic of French, which isolates it from the other Romance languages.
} 
(24) a. Spanish

i. Inmolasteis un novillo a aquel dios para el cual no offer-PST-2PL a calf to that-M.SG god for the which not era lícito.

DET be-PST.3sg licit-M.SG

'You offered a calf to that god for whom it was not licit.'

ii. Inmolasteis un novillo a aquél para el cual no offer-PST-2PL a calf to that-M.SG for the which not era lícito. Pro be-PST.3sg licit-.sG

'You offered a calf to that one for whom it is was not licit.'

b. Italian

i. Avete sacrificato un vitello a quella divinità alla quale non era permesso. DET

ii. ?Avete sacrificato un vitello a quella alla quale non era permesso. Pro

(Cicero, De Inventione II, 95)

Another aspect of the entrenchment of the DET $+\mathrm{N}$ pattern relates to the noun: to what extent is its presence obligatory (see question (iv) above)? As is shown in (27)(30) below, in combination with the definite article, only Spanish freely allows noun ellipsis, with an adjective, or with an adnominal PP (25b) - a pattern also attested in Old French (25a) - or a relative clause:

(25) a. Old French:

Il abati ton cheval et le Perceval ensemble.

he kill-PST.3sg your-M.SG horse.sG and the Perceval together

(Graal, $13^{\text {th }}$ C.)

b. Spanish:

Mató tu caballo y el de Perceval juntos.

kill-PST.3sG your-SG horse-sG and the of Perceval together-M.PL

'He killed your horse and that of Perceval at the same time.'

Insofar as the Spanish definite article $e l$ is homonymous (except for the stressed vowel in case of the pronoun) with the $3^{\text {rd }}$ singular personal pronoun él (Bosque and Demonte 2000: 818-23), the personal pronoun in (26) can be considered to be the final stage of a noun ellipsis:

(26) Spanish:

El hombre llegó ayer. / Él llegó ayer.

'The man arrived yesterday. / He arrived yesterday.'

The examples in (27)-(30) show, moreover, that Italian is rather similar to Modern French in that it no longer allows a relative clause nor a PP after the definite article. In contrast with French however, noun ellipsis with adjectives appears to be less restrictive, e.g. IT (preferisco) il caro vs FR ?* (je préfère) le cher (Renzi and Salvi 1988: 361). ${ }^{16}$

\footnotetext{
${ }^{16}$ In French, in certain cases, noun ellipsis with adjectives is possible, but it is limited to a particular type, namely classifying adjectives (Corblin et al. 2004:27), which include
} 
(27) Noun ellipsis: Article + AdJective

a. Spanish

i. Prefiero el rojo / el caro.

'I prefer the red / the expensive.'

ii. Lo bonito de la historia es que ...

'The beauty of the story is that ...'

b. Italian

i. Preferisco il rosso / il caro.

'I prefer the red / the expensive.'

ii. Il bello della storia è che ...

'The beauty of the story is that ...'

c. French

i. Je préfere le rouge / ?* le cher.

ii. ?*Le beau de l'histoire est que...

(28) Noun ellipsis: Article + PP

a. Spanish

Escogió el de su padre.

choose-PST.3SG the of his father

'He chose his father's.'

b. Italian

??Scegliò il di suo padre. (archaic)

'He chose his father's.'

c. Old French

Il abati ton cheval et le Perceval ensemble.

(Graal)

(29) Noun ellipsis: Article + Relative Clause (Spanish only)

Escogió el que su padre llevaba.

choose-PST.3SG the which his father wear-IMPF.3sG

'He chose the one his father was wearing.'

(30) Noun ellipsis: ARTICLE $=$ PRONOUN (Spanish only)

el (article, M.SG); él (pronoun, 3SG)

The differences between the degree of entrenchment of the NP pattern DET $+\mathrm{N}$ in the three Romance languages is furthermore confirmed by the fact that the noun slot can be occupied by morpho-syntactic categories other than nouns (see question (v) above). In combination with the definite article, both Spanish and Italian still allow an infinitive, again as was the case in Old French.

(31) a. Old French

$\begin{array}{lllll}\text { A } & \text { l' } & \text { issir } & \text { une maison } & \text { virent. } \\ \text { At } & \text { DEF.ART } & \text { leave-INF } & \text { a house } & \text { see-PST.3PL }\end{array}$

superlatives, color adjectives, measure adjectives (e.g. le petit) and hierarchical adjectives (e.g. le premier). 
b. Spanish

$\begin{array}{llll}\text { Al } & \text { salir } & \text { vieron } & \text { una casa. } \\ \text { At-DEF.ART. } & \text { leave-INF } & \text { see-PST.3PL } & \text { a house }\end{array}$

c. Italian

All' uscire, videro una casa.

At-DEF.ART leave-INF see-PST.3PL a house

'Upon leaving they saw a house.'

(Chrétien de Troyes, Le Chevalier de la Charrette, v. 2511)

In Modern French, a remnant of this combination can only be found in lexicalized cases such as le coucher de soleil 'the sunset'. As (31b-c) show, in Spanish and Italian the combination of the definite article with the infinitive is still productive. However, in Italian, in contrast to Spanish, it cannot introduce finite complement clauses. Once more, Italian thus appears to resemble Spanish on the one hand, and French on the other, and can therefore be described as occupying the intermediate position among the three languages under analysis. The relevant data are shown in (32).

(32) ARTICLE + non-nominal morphosyntactic categories

a. ArTICLE + INFINITIVE

i. Spanish

El ladrar de un perro me molesta.

the bark-INF of a dog me bothers

'The barking of a dog bothers me.'

ii. Italian

L'abbaiare d'un cane mi disturba.

'The barking of a dog bothers me.'

iii. French

Le coucher de soleil (lexicalized)

b. Article + Complement clause

i. Spanish

El que el perro ladre es normal.

the that the dog barks is normal

'It's normal that the dog barks.'

ii. Italian

*Il che il cane abbaia è normale.

the that the dog barks is normal

iii. French

*Le que le chien aboie est normal.

\section{Conclusions}

We have analyzed the mechanisms involved in the development of two paradigms which did not exist in Latin but which emerged in Romance. While pragmatic factors played a decisive role in the emerging stage, we argue, following Fischer 
(2008) inter alia, that in the subsequent stages of the grammaticalization process, analogy is a crucial factor, in two ways.

On the one hand, the high token frequency of the combination DEFINITE ARTICLE + $\mathrm{N}$ leads to the creation of a syntagmatic ARTICLE $+\mathrm{N}$ pattern at type-level (patternfinding, Tomasello 2003). The same pattern will in turn be mapped onto an even more abstract DETERMINER $+\mathrm{N}$ type-level (system mapping, Tomasello 2003).

On the other hand, analogy also acts at a paradigmatic level: the slot initially occupied by the definite article attracts other items with a similar role, indefinite articles in the first stage, and subsequently, different types of determiners.

We have provided two types of evidence for our claim. French diachronic data convincingly show the correlation between the ongoing development of articles and determiners, and the restructuring of the NP, which shifts towards a strictly configurational pattern. Comparative Romance data confirm that there is a correlation between the stage of development of the articles and that of other determiners, on the one hand, and that the evolutionary stage of the two is linked to the degree of entrenchment of the NP pattern, on the other. Although the three Romance languages discussed here have developed articles and have grammaticalized the possessives, demonstratives and indefinites that they inherited from Latin into pre-nominal markers, they did so to a different extent. In several respects, the Spanish system resembles that of Old French (stage III). Thus, with respect to articles, we have observed a full-fledged definite article in contrast with a not fully grammaticalized indefinite article and a still frequent zero-marking. Furthermore, Spanish lacks a partitive article. As for its other determiners, their paradigm is not fully separate from the pronouns, and they display flexible word order within the NP. The Italian data, in turn, show similarities with Middle French (stage IV). With respect to the articles, our statistical data suggest, for example, that the indefinite article in Italian is further grammaticalized than in Spanish. Moreover, certain varieties of Italian have developed a partitive article, which however is still in competition with zero marking, as was the case in Middle French. Other determiners in Italian do not correspond to a separate paradigm, as in Spanish, but they are more constrained syntagmatically, which brings Italian closer to French.

In conclusion, we again quote Meillet (1912: 133):

Tandis que l'analogie peut renouveler le détail des formes, mais laisse le plus souvent intact le plan d'ensemble du système existant, la « grammaticalisation » de certains mots crée des formes neuves, introduit des catégories qui n'avaient pas d'expression linguistique, transforme l'ensemble du système.

'While the analogy can renew the detail of forms but generally leaves the overall plan of the existing system intact, "grammaticalization" of certain words creates new forms, introduces categories that lacked linguistic expression, transforms the entire system.'

This article has shown that if we consider analogy, not as a similarity between concrete phonological forms (e.g. aime love-PRs.1SG / amons > aimons love-PRs.1PL), as Meillet did, but rather as a more abstract principle of similarity of form and function, acting both at the syntagmatic and the paradigmatic level, then analogy is a major factor contributing to the emergence of new morphosyntactic categories. 


\section{CORPORA}

\section{Electronic corpora}

BFM - Base de Français Médiéval [En ligne]. Lyon : ENS de Lyon, CNRS-IHRIM, 2016, <txm.bfm-corpus.org $>$.

DMF - Base du Dictionnaire du français médiéval. Nancy : CNRS-ATILF < http://www. atilf.fr/dmf>

Frantext. Nancy : CNRS-ATILF www.frantext.fr

\section{Parallel Corpus}

\section{Old French Translation}

W. Van Hoecke éd. La Rettorique de Marc Tulles Cyceron. La traduction par Jean d'Antioche (1282) du De Inventione de Cicéron et de la Rhetorica ad Herennium, édition électronique d'après le manuscrit unique. Mise à notre disposition par l'éditeur.

\section{Modern French TransLation}

G. Achard, éd.,1994, Cicéron. De l'Invention. Texte établi et traduit. Paris: Belles-Lettres.

H. Bornecque éd. 1932], Cicéron. De l'Invention (De Inventione). Texte revu et traduit avec introduction et notes, Paris: Belles-Lettres [1932].

\section{Spanish TRANSLATION}

Reyes Coria, Bulmaro, ed. 1997. M.T. Cicero. De la invención. Retórica, introducción, traducción y notas. México: Universidad Autónoma de México, Centro de Estudios Clásicos.

\section{ITALIAN TRANSLATION}

Greco, Maria, ed. 1998. Cicerone, M.T. De Inventione. Introduzione, traduzione e note a cura di. La Galatina: Congedo.

\section{REFERENCES}

Anttila, Raimo. 2003. Analogy: The Warp and Woof of Cognition. In The Handbook of Historical Linguistics, ed. Brian Joseph and R. Janda, 425-440. Oxford: Oxford University Press.

Bosque, Ignacio, and Violeta Demonte. 2000. Gramática descriptiva de la lengua española I. Madrid: Espasa.

Buridant, Claude. 2000. Grammaire nouvelle de l'ancien français. Paris: Sedes.

Bybee, Joan. 2003. Mechanisms of change in grammaticization: The role of frequency. In The Handbook of Historical Linguistics, ed. Brian Joseph and Richard Janda, 602-623. Oxford: Oxford University Press.

Carlier, Anne. 2007. From preposition to article: The grammaticalization of the French partitive. Studies in Language 31(1): 1-49.

Carlier, Anne. 2011. From multum to beaucoup: Between adverb and nominal determiner. In French determiners in and across time, ed. Lucia Tovena, 55-87. London: College Publications. 
Carlier, Anne. 2013. Grammaticalization in progress in Old French: Indefinite articles. In Research on Old French: The state of the art, ed. Deborah Arteaga, 45-60. Dordrecht: Springer.

Carlier, Anne, and Bernard Combettes, eds. 2015. Une tendance évolutive du français: la spécialisation de la catégorisation morphosyntaxique. Langue française 187.

Carlier, Anne, and Céline Guillot. 2018. The restructuring of demonstrative paradigm in the passage from Latin to French. In Latin tardif - ancien français: continuités et ruptures, ed. Anne Carlier and Céline Guillot, 201-231. Berlin: De Gruyter.

Carlier, Anne, and Béatrice Lamiroy. 2014. The grammaticalization of the prepositional partitive in Romance. In Partitive cases and related categories, ed. Silvia Luraghi and Tuomas Huumo, 477-523. Berlin: Mouton De Gruyter.

Carlier, Anne, and Walter De Mulder. 2010. The emergence of the definite article in Late Latin: ille in competition with ipse. In Subjectification, intersubjectification and grammaticalization, ed. Kristin Davidse, Lieven Vandelanotte, and Hubert Cuyckens, 241-275. The Hague: Mouton De Gruyter.

Carlier, Anne, Béatrice Lamiroy, and Walter De Mulder. 2012. The pace of grammaticalization in Romance. Folia Linguistica, 46(2): 287-301.

Combettes, Bernard. 2001. L'émergence d'une catégorie morphosyntaxique: les déterminants du nom en français. Linx 45: 117-126.

Corblin, Francis, Jean-Marie Marandin, and Petra Sleeman. 2004. Nounless determiners. In Handbook of French semantics, ed. Francis Corblin and Henriëtte de Swart, 23-40. Standford: CSLI publications.

Fischer, Olga. 2008. On analogy as the motivation for grammaticalization. Studies in Language 32(2): 336-382.

Fruyt, Michèle. 2010. L'emploi de is, hic, iste, ille, ipse en latin archaïque et classique. Revue des études latines 87: 44-78.

Gisborne, Nikolas, and Amanda Patten. 2011. Construction grammar and grammaticalization. In The Oxford handbook of grammaticalization, ed. Heiko Narrog and Bernd Heine, 92-105. Oxford: Oxford University Press.

Harris, Martin. 1978. The evolution of French syntax: A comparative approach. London: Longman.

Lahousse, Karen, and Béatrice Lamiroy. 2012. Word order in French, Spanish and Italian. A grammaticalization account. Folia Linguística, 46(2): 387-417.

Lamiroy, Béatrice. 1999. Auxiliaires, langues romanes et grammaticalisation. Langages 33 (135): 33-45.

Lamiroy, Béatrice. 2003. Grammaticalisation et comparaison de langues. Verbum 24(4): 409-430.

Lamiroy, Béatrice, and Walter De Mulder. 2011. Degrees of grammaticalization across languages. In The Oxford handbook of grammaticalization, ed. Heiko Narrog and Bernd Heine, 302-317. Oxford: Oxford University Press.

Marchello-Nizia, Christiane. 1992. Histoire de la langue française au XIVe et XVe siècles. Paris: Dunod.

Meillet, Antoine. 1912. L'évolution des formes grammaticales. Scientia 12: 384-400, reprinted in Linguistique historique et linguistique générale. Paris: Champion, 1982.

Menge, Hermann. 2000. Lehrbuch der lateinischen Syntax und Semantik [Textbook of Latin syntax and semantics]. Darmstadt: Wissenschaftliche Buchgesellschaft.

De Mulder, Walter, and Anne Carlier. 2006. Du démonstratif à l'article défini: le cas de ce en français moderne. Langue française 152(4): 96-113. 
De Mulder, Walter, and Anne Carlier. 2012. Definite articles. In The Oxford handbook of grammaticalization, ed. Heiko Narrog and Bernd Heine, 92-104. Oxford: Oxford University Press.

De Mulder, Walter, and Béatrice Lamiroy. 2012. Gradualness of grammaticalization in Romance: The position of French, Spanish and Italian. In Grammaticalization and language change: New reflections, ed. Kristin Davidse, Tine Breban, Lieselotte Brems and Tanja Mortelmans, 199-227. Amsterdam: John Benjamins.

Van Peteghem, Marleen. 2000. Les indéfinis. In De l'indétermination à la qualification: Les indéfinis, ed. Léonie Bosveld, Marleen Van Peteghem, Danièle Van de Velde, 117202. Arras: Artois Presses Université.

Renzi, Lorenzo, and Giampaolo Salvi. 1988. Grande grammatica italiana di consultazione I [Italian reference grammar]. Bologna: Il Mulino.

Stark, Elisabeth. 2007. Gender, Number and indefinite articles. About the typological inconsistency of Italian. In Nominal Determination: Typology, Context Constraints and Historical Emergence, ed. Elisabeth Stark, Elisabeth Leiss, and Werner Abraham, 4971. Amsterdam: John Benjamins.

Selig, Maria. 1992. Die Entwicklung der Nominaldeterminanten im Spätlatein: Romanischer Sprachwandel und lateinische Schriftlichkeit [The development of the nominal determinants in late Latin: Romance language and Latin writing]. Tübingen: Gunter Narr.

Tomasello, Michael. 2003. Constructing a language: A usage-based theory of language acquisition. Cambridge: Harvard University Press.

Traugott, Elizabeth C., and Graeme Trousdale. 2013. Constructionalization and constructional changes. Oxford: Oxford University Press. 